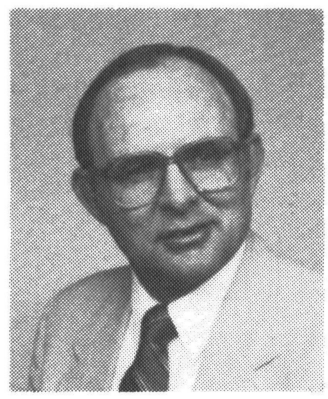

Editorial

Jack D. Gaskill, Editor

\section{Status of Optical Engineering}

I thought that the readers of Optical Engineering might be interested in a brief look at the status of the Journal, and with that in mind, I prepared the following chart. The figures under the 1985 column are actual figures, whereas those under the 1986 column are estimates based on the publication data available for the first nine issues of this year.

\begin{tabular}{|c|c|c|c|}
\hline & 1985 & 1986 (est.) & Est. change \\
\hline $\begin{array}{l}\text { No. papers published on } \\
\text { special-issue topics }\end{array}$ & 104 & 98 & $-6 \%$ \\
\hline $\begin{array}{l}\text { No. additional contributed } \\
\text { papers published }\end{array}$ & 88 & 94 & $+7 \%$ \\
\hline Total no. papers published & 192 & 192 & $0 \%$ \\
\hline $\begin{array}{l}\text { No. pages technical } \\
\text { text published }\end{array}$ & 1093 & 1312 & $+20 \%$ \\
\hline $\begin{array}{l}\text { Average no. pages per } \\
\text { technical paper }\end{array}$ & 5.7 & 6.9 & $+21 \%$ \\
\hline $\begin{array}{l}\text { Percentage technical pages } \\
\text { paid for by authors }\end{array}$ & $74 \%$ & $70 \%$ & $-4 \%$ \\
\hline
\end{tabular}

Note that although the total number of papers is the same for each year, in 1986 the number of pages is expected to increase by $20 \%$ and the number of pages per paper by $21 \%$. It is difficult to determine the cause with certainty, but we believe that most of these increases are a result of changes in the Journal format; perhaps half is due to the increased type size and the other half to the addition of authors' photographs and biographical sketches.

You might also note that the percentage of pages supported by page charges is expected to be $70 \%$, down $4 \%$ from last year. This brings up a somewhat controversial subject, because some authors cannot pay page charges and others do not think that they should be required to pay them-particularly if they have been invited to submit a paper. While I certainly understand, the publication of Optical Engineering depends to some degree on publication charge support from authors, with the present budget based upon receipt of page charges from approximately $80 \%$ of the authors. Page charges may eventually go the way of the dinosaurs, but they are with us for the time being.

I hope this glimpse at the status of the Journal has been informative, and I welcome your comments and questions.
Future Special Issue (see p. 1038 for complete editorial schedule)

July 1987

\section{Visual Communications and Image Processing}

\section{Guest Editor: T. Russell Hsing}

Room 2L-181

Bell Communications Research

435 South Street

Morristown, NJ 07960-1961 201/829-4950

The increase in communication of visual information over the past several decades has resulted in many new image processing and visual communications systems being put into service. The growth of this field has been rapid in both commercial and military applications. With the growing availability of optical fiber links, advances of large scale integration, new telecommunications services, and emerging new processing algorithms, computer technologies, fiber optics technologies, and VLSI devices, this growth undoubtedly will continue and will create many more video services of value to huge numbers of customers. Therefore, a special issue on Visual Communications and Image Processing is being planned for publication in July 1987. Papers in the issue will include, but not be limited to, the following topics:

- PC-based image processing systems

- Image processing for telecommunications

- Image understanding and knowledge-based systems

- Human visual system models for image processing

- Optical fiber based network distribution for image data

- Pattern recognition and image processing for medical applications

- High definition television

- Electronic publishing and facsimiles.

Prospective authors wishing to have their manuscripts considered for publication in this issue should submit four copies of their complete manuscripts to the Guest Editor for review by November 1, 1986. 